\title{
MATERNAL DEFENSIVE BEHAVIOR OF MOUNTAIN GOATS AGAINST PREDATION BY GOLDEN EAGLES
}

\author{
Sandra Hamel ${ }^{1,2}$ and Steeve D. Côté ${ }^{1}$
}

\begin{abstract}
Maternal defensive behavior against predators may appear risky but is common in many species. Herein we describe maternal defensive behavior of mountain goats (Oreamnos americanus) against Golden Eagle (Aquila chrysaetos) predatory attempts. We found that Golden Eagles attacked goats in $1.9 \%$ of sightings $(n=311$ sightings of active Golden Eagles over 12 years) but were never successful. Mothers always defended their young against Golden Eagle attacks. Predation by Golden Eagles on young-of-the-year appears low for most ungulate species, including mountain goats. The benefits of defending offspring against eagles are likely high in ungulates, and we would therefore expect selection to favor maternal defensive behavior.
\end{abstract}

Key words: ungulates, avian predator, maternal defense, mountain goats.

Maternal defensive behavior against predators is common in many taxa, including large ungulates (Lipetz and Bekoff 1980, Smith 1987, Scotton and Pletscher 1998). For instance, female moose (Alces alces; Stephenson and Van Ballenberghe 1995) and mountain goats (Oreamnos americanus; Côté et al. 1997) can defend their young against attacking wolves (Canis lupus). Bighorn sheep (Ovis canadensis; Berger 1978) and mule deer (Odocoileus hemionus; Hamlin and Schweitzer 1979) females can charge and chase coyotes (Canis latrans). Although juvenile ungulates are more vulnerable than their mothers, these predators have the abilities to harm and kill adults. Therefore, maternal defensive behavior appears risky.

Mountain goats cohabit with many predators, such as wolves, grizzly bears (Ursus arctos), black bears (Ursus americanus), cougars (Puma concolor), coyotes, wolverines (Gulo luscus), and Golden Eagles (Aquila chrysaetos; FestaBianchet et al. 1994, Côté and Beaudoin 1997, Côté et al. 1997). Golden Eagles prey upon both juveniles and adults of many ungulate species, such as bighorn sheep (Bleich et al. 2004), pronghorn (Antilocapra americana; Goodwin 1977, Deblinger and Alldredge 1996, Beckmann and Berger 2005), red deer (Cervus elaphus; Cooper 1969, Northeast 1978), freeranging domestic sheep (Ovis aries; Warren et al. 2001), and caribou and semidomestic reindeer (Rangifer tarandus; Nybakk et al. 1999, 2002, Valkenburg et al. 2004). Brandborg (1955) and Smith (1976) both reported 2 cases of Golden Eagles preying on mountain goat kids, whereas Anderson (1940) reported that eagles tried to knock goats off cliff faces and were successful on one occasion. Here, we describe maternal defensive behavior of free-ranging mountain goats against Golden Eagle predatory attempts.

We observed Golden Eagles during a longterm study of marked mountain goats at Caw Ridge, west central Alberta $\left(54^{\circ} \mathrm{N}, 119^{\circ} \mathrm{W}\right)$, Canada. Caw Ridge is a mountain complex of gently rolling hills at about $2000 \mathrm{~m}$ elevation. Alpine meadows are common and interspersed by cliff ledges and steep scree slopes (for more details on the study area see Côté and FestaBianchet 2001a, 2001b). From 1994 to 2005, between mid-May and the end of September, we recorded 324 sightings of Golden Eagles (active and inactive) in the study area during approximately 12,000 hours of observation on mountain goats. Most observations (91\%) were of solitary eagles. Nearly all eagles $(96 \%$ of observations) were active and flying in proximity of mountain goats.

The distribution of Golden Eagle sightings varied little over the summer, except for 2 small peaks in early and late summer (Fig. 1). Active Golden Eagles attacked goats in 1.9\% of 311 sightings and were never successful. On 1 June 1997, an adult eagle attacked a group of 3 nannies with their kids, when the kids were about a week old. Immediately,

\footnotetext{
${ }^{1}$ Département de biologie et Centre d'études nordiques, 1045 avenue de la Médecine, Université Laval, Québec, Canada, GIV 0A6.

${ }^{2}$ E-mail: sandra.hamel@uit.no
} 


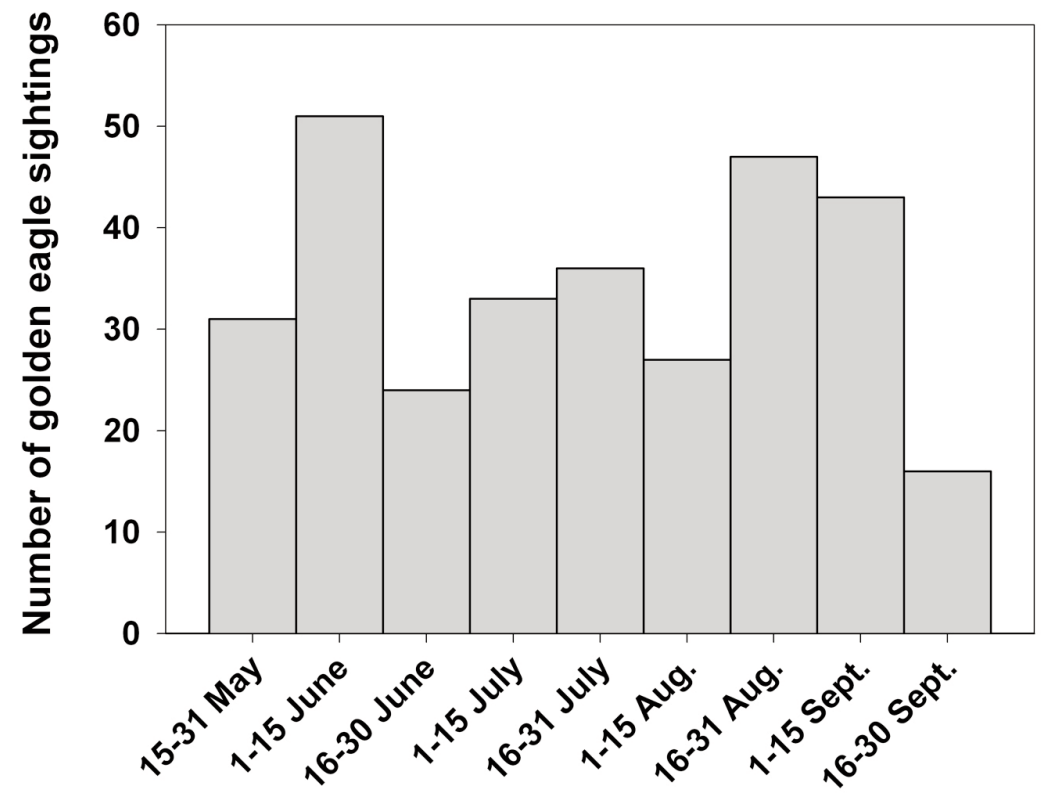

Fig. 1. Distribution of Golden Eagle sightings at Caw Ridge, Alberta, during summer between 1994 and 2005.

mothers and kids, initially separated by $1.5-3$ $\mathrm{m}$, ran towards each other, and the kids hid underneath their mothers. The eagle made only one attack, which lasted 20 seconds. The females stayed alert for about one minute but remained nervous for the next hour. On 7 June 2002, an adult Golden Eagle flew near a nursery group of 16 individuals including 1 kid. The kid immediately ran towards its mother. On 29 May 2005, a nanny and her kid were attacked twice by an adult Golden Eagle. The mother, with her kid about $2 \mathrm{~m}$ distant, was foraging near a cliff when the eagle made its first attempt, diving at $5 \mathrm{~m}$ above the goats. As soon as the eagle was close, the mother quickly ran towards her kid to hide it underneath her. The eagle glided above them for about 30 seconds while the mother kept on stamping the ground. Once the eagle had moved away, the mother led her kid underneath an overhanging cliff, where the kid bedded. The mother stood in front of her kid, hiding it, and remained alert for 8 minutes. She then bedded at the same location. An hour later, the eagle attacked the same goat pair. The mother and her kid performed similar behaviors and hid in the same location. On 14 September 2005, an adult Golden Eagle dived at approximately $10 \mathrm{~m}$ above a nanny and her kid that were bedded in a grassy patch above a cliff. The pair promptly stood up, and the mother hid her kid behind her. She remained alert for 3 minutes and then resumed bedding.

On 2 other instances, we observed Golden Eagles attacking adult males. In June 2003, two adult Golden Eagles interacted with a 5year-old male for 30 seconds. The male goat performed horn tosses at the eagles when they approached closer than $10 \mathrm{~m}$. In September 2004, two Golden Eagles, an adult and a juvenile, attacked 3 groups of adult males that were bedded in proximity to one another. The males stood up and gave horn tosses.

Unlike Anderson (1940), we never witnessed Golden Eagles trying to knock goats off cliffs. Golden Eagle predatory attempts directed at goat kids were rare but seemed more frequent in the spring (3 out of 4 attempts on kids), when kids were lighter and less agile and hence more vulnerable to predation than they were later in the summer. Although kids appeared to instinctively run underneath their mothers when they saw an eagle, females also defended their young against Golden Eagle attacks. Maternal defensive behavior against Golden Eagles has also been reported in other alpine ungulates, such as chamois (Rupicapra rupicapra) and Dall's sheep (Ovis dalli dalli; Nette et al. 1984, Locati 1990, Bertolino 2003). Similar to what we observed in mountain goats, 
females of these species protected their young from Golden Eagles by sheltering them underneath their bellies and by threatening the eagles. In our study area, we also witnessed a Golden Eagle attacking a bighorn ewe and her lamb, and they reacted similarly. Our observations of maternal defensive behavior and offspring reactions to avian predators are also consistent with antipredatory defense reported against terrestrial predators (Kruuk 1972, Lingle et al. 2005).

Even if directly facing predators is risky, maternal defensive behavior has been observed in many species of ungulates (Lent 1974). However, maternal defensive behavior against Golden Eagles is not as risky as it would be against other larger predators, because the chance that an adult ungulate would be preyed upon by a Golden Eagle is very low. In addition, predation by Golden Eagles on youngof-the-year appears low for most ungulate species, including mountain goats. Most female ungulates wean $<10$ offspring during their lifetime, and hence each offspring is very valuable. For many species, losing a young means skippiing an entire year of reproduction. It is not surprising, therefore, to expect maternal defensive behavior to occur against predators, particularly against those predators that are not fatal for adults, such as Golden Eagles. As previously suggested for other ungulates (Smith 1987, Stockwell 1991, Bleich 1999), we conclude that the benefits of defending offspring against eagles are likely high in mountain goats, and we should therefore expect selection to favor maternal defensive behavior.

Our research was financed by the Alberta Conservation Association, the Alberta Fish and Wildlife Division, the Natural Sciences and Engineering Research Council of Canada, the Rocky Mountain Goat Foundation, and the Universities of Sherbrooke and Laval. We are grateful to the many people who helped with fieldwork at Caw Ridge over the years. The research was conducted in accordance with Canadian laws and guidelines.

\section{Literature Cited}

Anderson, N.A. 1940. Mountain goat study. State of Washington Department of Game, Olympia Biology Bulletin 2.

Beckmann, J.P., and J. Berger. 2005. Pronghorn hypersensitivity to avian scavengers following Golden Eagle predation. Western North American Naturalist 65: $133-135$.

Berger, J. 1978. Maternal defensive behavior in bighorn sheep. Journal of Mammalogy 59:620-621.

Bertolino, S. 2003. Herd defensive behaviour of chamois, Rupicapra rupicapra, in response to predation on the young by a Golden Eagle, Aquila chrysaetos. Zeitschrift für Jagdwissenschaft 49:233-236.

BLEICH, V.C. 1999. Mountain sheep and coyotes: patterns of predator evasion in a mountain ungulate. Journal of Mammalogy 80:283-289.

Bleich, V.C., E.F. Cassirer, V.L. Coggins, L.E. OldenBURG, AND D.E. HunTER. 2004. Predation by a Golden Eagle, Aquila chrysaetos, on a juvenile mountain sheep, Ovis canadensis. California Fish and Game 90:91-93.

BRANDBorg, S.M. 1955. Life history and management of the mountain goat in Idaho. State of Idaho Department of Fish and Game, Wildlife Bulletin 2.

Cooper, A.B. 1969. Golden Eagle kills red deer calf. Journal of Zoology 158:215-216.

CôTÉ, S.D., AND C. BEAUdoin. 1997. Grizzly bear (Ursus arctos) attacks and nanny-kid separation on mountain goats (Oreamnos americanus). Mammalia 61:614-617.

Côté, S.D., And M. Festa-Bianchet. 2001a. Birthdate, mass and survival in mountain goat kids: effects of maternal characteristics and forage quality. Oecologia 127:230-238.

2001b. Reproductive success in female mountain goats: the influence of maternal age and social rank. Animal Behaviour 62:173-181.

Côté, S.D., A. Peracino, ANd G. Simard. 1997. Wolf, Canis lupus, predation and maternal defensive behavior in mountain goats, Oreamnos americanus. Canadian Field-Naturalist 111:389-392.

Deblinger, R.D., And A.W. Alldredge. 1996. Golden Eagle predation on pronghorns in Wyoming's Great Divide Basin. Journal of Raptor Research 30:157-159.

Festa-Bianchet, M., M. Urouhart, and K.G. Smith. 1994. Mountain goat recruitment: kid production and survival to breeding age. Canadian Journal of Zoology 72:22-27.

GoodwIN, G.A. 1977. Golden Eagle predation on pronghorn antelope. Auk 94:789-790.

Hamlin, K.L., AND L.L. SCHWEITZER. 1979. Cooperation by coyote pairs attacking mule deer fawns. Journal of Mammalogy 60:849-850.

KruUk, H. 1972. The spotted hyena. University of Chicago Press, Chicago, IL.

LENT, P.C. 1974. Mother-infant relationships in ungulates. Pages 14-55 in V. Geist and F. Walther, editors, The behaviour of ungulates and its relation to management. IUCN, Morges, Switzerland.

Lingle, S., S.M. Pellis, and W.F. Wilson. 2005. Interspecific variation in antipredator behaviour leads to differential vulnerability of mule deer and whitetailed deer fawns early in life. Journal of Animal Ecology 74:1140-1149.

LipetZ, V.E., AND M. BEKOFF. 1980. Possible functions of predator harassment in pronghorn antelopes. Journal of Mammalogy 61:739-741.

Locati, M. 1990. Female chamois defends kids from eagle attacks. Mammalia 54:155-156.

Nette, T., D. Burles, AND M. Hoefs. 1984. Observations of Golden Eagle, Aquila chrysaetos, predation on Dall sheep, Ovis dalli dalli, lambs. Canadian FieldNaturalist 98:252-254. 
Northeast, C.J. 1978. Golden Eagle persistently attacking red deer calf. British Birds 71:36-37.

NybakK, K., O. KJelvik, and T. Kvam. 1999. Golden Eagle predation on semidomestic reindeer. Wildlife Society Bulletin 27:1038-1042.

Nybakk, K., O. Kjelvik, T. Kvam, K. Overskaug, and P. Sunde. 2002. Mortality of semi-domestic reindeer Rangifer tarandus in central Norway. Wildlife Biology 8:63-68.

Scotton, B.D., And D.H. Pletscher. 1998. Evaluation of a capture technique for neonatal Dall sheep. Wildlife Society Bulletin 26:578-583.

SMITH, B.L. 1976. Ecology of Rocky Mountain goats in the Bitterroot Mountains, Montana. Master's thesis, University of Montana, Missoula.

Sмiтh, W.P. 1987. Maternal defense in Columbian whitetailed deer: when is it worth it? American Naturalist 130:310-316.
Stephenson, T.R., And V.V. Ballenberghe. 1995. Defense of one twin calf against wolves, Canis lupus, by a female moose, Alces alces. Canadian Field-Naturalist 109:251-253.

StOckWELL, C.A. 1991. Behavioural reactions of desert bighorn sheep to avian scavengers. Journal of Zoology 225:563-566.

Valkenburg, P., M.E. McNay, and B.W. Dale. 2004. Calf mortality and population growth in the Delta caribou herd after wolf control. Wildlife Society Bulletin 32:746-756.

Warren, J.T., I. Mysterud, and T. Lynnebakken. 2001. Mortality of lambs in free-ranging domestic sheep (Ovis aries) in Northern Norway. Journal of Zoology 254:195-202.

Received 12 December 2007 Accepted 11 June 2008 